\title{
Twenty Years of Restorative Justice in Belgian Prisons: Traces and Critical Questions \\ Christophe Dubois,.c.dubois@uliege.be
}

\begin{abstract}
This article accounts for a prison policy initiated in Belgium in 1998 that aimed at re-shaping the culture of detention towards a culture of 'restorative justice'. This analysis first illuminates the relationship between knowledge and policy in the policymaking process, but also in the top-down implementation process. The article then assesses the current embeddedness of restorative justice ideas and practices in Flemish and French-speaking prison policies. The discussion finally points out some critical questions raised by the concept of restorative justice, its political and legal inscriptions (Freeman \& Sturdy, 2015), and some of the paradoxes it entails in terms of 'institutionalised alternative' (Bastard \& Cardia-Vonèche, 2000) and 'retribution and/or restoration' (Albrecht, 2011; Pavlich, 2013).
\end{abstract}

Keywords: Restorative justice - policymaking - policy implementation - policy embeddedness - controversies

\section{Résumé}

Cet article rend compte d'une politique pénitentiaire initiée en Belgique en 1998, visant à orienter la culture de la détention vers une culture de justice réparatrice. Cette analyse éclaire d'abord le rôle des savoirs dans le processus d'élaboration des politiques publiques, mais aussi dans le processus de mise en œuvre vertical de la politique étudiée. L'article évalue ensuite l'actuel encastrement politique des idées et des pratiques de justice réparatrice dans les structures d'action publique flamandes et francophones. La discussion souligne enfin quelques ques- 


\section{Dubois Christophe}

tions critiques soulevées par le concept de justice réparatrice, ses inscriptions politiques et juridiques (Freeman \& Sturdy, 2015), et certains des paradoxes que cela implique en termes d' "alternative institutionnalisée" (Bastard \& Cardia-Vonèche, 2000) et de "rétribution et / ou restauration" (Albrecht, 2011, Pavlich, 2013).

Mots clés: Justice réparatrice - conception des politiques publiques mise en œuvre des politiques publiques - encastrement politique - controverses

\section{Introduction}

In the last twenty years, restorative justice has become a fashionable source of innovative criminal justice policy in many countries around the world (Dhami et al., 2009). This model of justice 'typically involves having victims, offenders, and community members come together to find a way to restore the relationships harmed by an offense' (Crocker, 2015: 45). Combining victim-offender mediation practices (Dubois, 2008a) and an increasing concern for the victims of crimes, restorative justice programmes took place in the prison of Turin in the early 2000s (Guidoni, 2003), and more recent initiatives have been developed in France (Abdellaoui et al., 2016). Most of these initiatives refer to the 'notable' Belgian example. If some have been critically assessed (Albrecht, 2011), the present article aims to provide a descriptive, analytical and critical account of the policymaking and implementation processes of the policy initiated in Belgium in 1998. That policy aimed at re-shaping the culture of detention towards a culture of 'restorative justice'. This analysis illuminates the relationship between knowledge and policy (Freeman \& Sturdy, 2015) in the policymaking process (section 1), and its unprepared implementation process (section 2). I then assess the current embeddedness (Laville, 2001) of restorative justice ideas and practices in Flemish and French-speaking prison policies (section 3). The discussion (section 4) finally points out some critical questions raised by the concept of restorative justice, its political and legal inscriptions (Freeman \& Sturdy, 2015) ${ }^{1}$, and some of the paradoxes it entails

\footnotetext{
${ }^{1}$ The typology elaborated by Freeman and Sturdy (2015) considers that knowledge
} is often 'embodied' in people, 'inscribed' in documents and instruments, or 'enact- 


\section{Dubois Christophe}

in terms of an 'institutionalised alternative' (Bastard \& Cardia-Vonèche, 2000) and 'retribution and/or restoration' (Albrecht, 2011; Pavlich, 2013).

This article draws on the results of my $\mathrm{PhD}$ thesis for which interview and observational data were collected between January 2005 and April 2009 in four Belgian prisons (Dubois, 2012a). Semi-structured interviews were then conducted with 90 prison workers (guards, psychosocial workers, prisoners, restorative justice advisers and NGOs). I also collected and analysed the annual reports of the Mediante and Suggnomé associations, both of which are approved as (victim-offenders) mediation services.

\section{A top-down policy-making process}

With the ministerial circular of October $4^{\text {th }}$ 2000, the Minister for Justice decided to redefine the function of Belgian prisons as one of restoration. The genesis of this circular, analysed elsewhere (Dubois, 2008a), reports on a scientific programme feeding a policy programme.

The scientific programme has its roots in the 1990s with the emergence of a research subject within the 'penology and victimology' team at K.U. Leuven, directed by Prof Tony Peters: restorative justice (RJ hereafter). Two fundamental lines of research were conducted on this topic. First, a pilot project launched in 1993 aimed at assessing the opportunity for victim-offender mediation experiments at the court level (Aertsen, 2006). Two associations were created to manage these mediations: Suggnomé in Flanders and Mediante in Wallonia. It should be noted that, in order to regularize the pilot experiments already carried out by scientists and practitioners, the law of 22 June 2005 instituted mediation services for serious offenses ${ }^{2}$ at every stage of the criminal justice process.

A second line of research was inspired by certain overseas experiments such as the Victim-Offender reconciliation programmes in Canada, England and the United States (Immarigeon, 1996). In the conviction that RJ (restorative justice) should not end before the prison walls, the K.U. Leuven team initiated an action research entitled herstelgerichte detentie, which means a restorative approach to detention (Robert \& Peters, 2002). This approach was commissioned by the Minister of Justice in December 1998 and was con-

ed' in interaction with others. Every occurrence of "inscription" in this article will refer to this meaning.

${ }^{2}$ Since 10 March' 2006, through a Ministerial ruling, Médiante and Suggnomè were approved as mediation services as defined in article 554, $§ 1$ of the criminal instruction code. 


\section{Dubois Christophe}

ducted with the Department of Criminology at the University of Liège, directed by Professor Georges Kellens. The action research aimed to define the conditions under which a restorative approach should be applied in prison facilities. In six prisons, six researchers experimented with various initiatives aimed at involving the prisoners in a process of financial and symbolic restoration.

At the prison of Tournai, the researcher requested the association Aide et Reclassement to test a programme of compensation as a pilot project. At the Central prison of Leuven, the association Suggnomé was asked to adapt their method to prisoners who wished to contact their victim. A similar experiment was attempted in a French-speaking prison, with the help of the association Mediante. The research teams also provided training for the prisoners to make them more aware of the consequences of their actions for the victims, with the help of the associations Slachtoffer in Beeld in Flanders, and Arpège-Prélude in Wallonia.

In December 1999, the action research report concluded that it was possible to adopt a restorative approach in detention. The Minister of Justice was then very quick to seize on these results.

'Neither Prof Kellens nor I expected an official text to be completed so rapidly. We were surprised in October 2000 to discover that a circular had been released announcing the appointment of 30 Restorative Justice Advisers (RJAs) (Tony Peters, December 2005).

The ministerial circular published on 4 October 2000 announced that all 31 Belgian prisons would start moving towards an RJ-oriented model. The wording of the circular that set out the framework within which the model should be implemented, was somewhat vague and general as it mentioned as a main objective to re-shape the culture of detention towards a culture of RJ. This task was delegated to new actors within the prison system, called Restorative Justice Advisers (RJAs). One RJA was appointed in each prison, with the responsibility of implementing the new prison policy.

The genetic process of the circular illuminates the role of research in the restorative detention policy. If $\mathrm{RJ}$ and restorative detention have been relayed by different research topics in the field of criminology at the University of Liège, RJ has been institutionalized - along with victimology - as a specific domain within the K.U. Leuven Institute of Criminology. An international network of research ${ }^{3}$, teaching (Vandekerckhove \& Doms, 2001) and publi-

\footnotetext{
${ }^{3}$ For example, the headquarters for the European Union Forum for Restorative Justice is located in Leuven (http://www.euforumrj.org).
} 


\section{Dubois Christophe}

cation (Vanspauwen et al., 2003) contributed to the development of this Institute. Its national and international renown positioned its members at the centre of one - among others - specific policymaking process leading Prof Lieven Dupont to be commissioned to draft a new Prison Act. It became the prison law on 12 January 2005 (B.S. 1 February 2005), and the idea(1) of RJ is inscribed in Article 9, which states as follows: 'The execution of the custodial sentence focuses on the restoration of the harm caused to the victims by the offense, on the rehabilitation of the convicted person and on the individualized preparation of his reintegration into the free society'. This inscription is discussed below (see infra, section 4).

The genesis of the circular also highlights the fact that this text did not result from any request emanating from prison officers, prison governors, prisoners, or the psychosocial teams (PST). How could these groups of actors therefore have been 'interested' in its implementation without any specific information and training sessions prior to the arrival of the RJAs into Belgian prisons? The circular was part of a policy decision thought up by researchers and the minister of Justice, from outside the prison administration. One can thus easily imagine the problems caused by its implementation in prisons, where the concept of RJ arrived at the same time as the RJAs in November 2000. There was no particular expectation associated with their arrival, which caused real problems for the RJAs during their first steps in prison, as described in the following section.

\section{An unprepared policy implementation process}

The nine pages of the circular of 4 October 2000 reveal an essentially axiological content. It clearly mentioned the restorative ideas that were intended to renew the prison culture. But there was no trace of any instruction clearly explaining how the RJAs should reach the objectives of the ministerial circular. The ambitious aim of the circular - to transpose the concept of RJ to the prison environment - was delegated to the RJAs, each of them being sent into one of the 31 prison establishments to this end.

The circular specified two characteristics of the RJAs. Firstly, their role was described as 'structural': 'transposing the RJ model into prison practice is part of a fundamentally structural approach [... and constitutes] a long-term challenge which must be adopted by all the prison management teams' (p. 3). Consequently, the mission of the RJA did not consist of managing RJ (oriented) actions on a case-by-case basis. Secondly, their 'position' was qualified as one of advisor to the prison governors. Consequently, they did not 


\section{Dubois Christophe}

appear in the hierarchical line of organisational charts. This was a major handicap in terms of integration into bureaucratic organisations that are organised on a pyramidal and hierarchical model drawn from military organisations. Bearing in mind the extent of their mission and the fact that they had no job description, we can get a better idea of the gamble that was their entry into service.

\subsection{Appointment}

These young people were recruited by the central administration in November 2000. Mainly female -23 out of 31 , entering gendered organizations as outlined by Britton (2003) - they were aged between 22 to 30, held a university degree in human and social sciences (nine of whom were criminologists, eleven were psychologists and thirteen were sociologists or anthropologists) and only a few of them had any professional experience prior to their entry into service. All of them, except for two who had worked on the action research project, were confronted with the prison environment and the concept of RJ for the first time.

From day one on the job, they discovered an environment shrouded in indifference (such as the prison guards 'trapped' in their daily routines) and sometimes hostility (such as some prison governors taking a dim view of new advisors being sent by the administration, perhaps to spy on them?) and, more generally, scepticism as expressed by one prison guard:

'Why bother sending us RJAs? To repair what? We need repair people for the heating, plumbers to fix the showers. But as far as the prisoners are concerned, they just want to do their time and to be left alone in peace' (an officer, October 2004).

Several RJAs were paralyzed by their situation and threw in the towel after a few weeks. Other candidates whose names were on the recruitment lists replaced them. Step by step, over time, the RJAs attempted to "carve out their niche' locally, whether to meet the challenge they had been set or simply to keep their jobs.

\subsection{A double phase of integration, at both collegial and local levels}

There were two spaces where RJAs eventually found their feet: a local space, the prison to which they had been assigned, and a supra-local space in the form of monthly collegial meetings called 'intervisions', which brought them together in the same language (Flemish or French) community. They 


\section{Dubois Christophe}

found in these meeting a space where they could gradually reduce their discomfort with the ambiguity of their mission.

In Flanders, as in Wallonia, intervisions were fulfilling two similar functions: one was to clarify RJAs' mission, the other to serve as a 'pressure valve' in the form of a sharing of the emotional difficulties encountered in the field.

In 2001, the Flemish RJAs started writing a concept paper in order to clarify their general mission and to come up with concrete action plans. In 2003 these documents were unanimously accepted by all of them. However, for the document to be published, it had to be approved by their French-speaking colleagues:

'In 2003, we had a clear paper. It was structured around the relationship between the offender and the victim. It detailed various types of approach and reflection that the offender could, or even should adopt towards his victim or victims. This document was formalised and only needed to be circulated. But for this to happen, it needed to be circulated at federal level. This was not possible because the French-speaking advisors were not ready' (a Flemish RJA).

Indeed, in the French-speaking community, the intervisions also allowed the CJRs to share the integration difficulties they each encountered locally. But disagreements quickly arose when they tried to clarify their mission. After two years of conflictual meetings, the practices of the RJAs varied so much from one prison to another that the process of writing a conceptual document was abandoned. They agreed, however, on a triangular diagram to define their mission.

'It was a triangle whose angles represented the offender, the victim and society. Arrows were drawn in two directions between each angle to show that the work of rebuilding relationships was dynamic. Can you see these circular arrows that join each angle to itself? The arrow which goes away from the offender and then returns to him signifies that the offender must work on himself, as well as on his victim and society in the wider sense. Each party must do this work on oneself' (a French-speaking RJA).

During the intervisions, both the French-speaking and Flemish-speaking RJAs managed to clarify their mission: through a minimalistic and consensual conception inscribed in a joint paper in Flanders, centred around the restoration of the connection between offender and victim; through a schematic, maximalist conception based on 'weak' compromise in Wallonia, illustrated by the triangle described above.

At a local level, the integration processes of the RJAs were extremely variable. They depended on the personal dispositions of the RJAs and especially 


\section{Dubois Christophe}

on the prison setting to which they were assigned. Depending on these contingent factors, the RJAs were granted a greater or lesser degree of legitimacy during their entry into service. They were therefore able to forge cooperative relations more or less easily with both internal (prison guards and governors, psychosocial teams, social workers, administrative staffs) and external stakeholders (prisoner assistance services, chaplaincy services, legal advice offices, mediation associations and trainers of all kinds). In addition, each prison granted them variable conditions of access to the prison population that were more or less receptive to the concept of $\mathrm{RJ}^{4}$.

These organisational characteristics had a significant impact on the exit decisions of many RJAs during the first six months of $2001(n=9)$. They also greatly determined the nature and the extent of the concrete work done locally by the RJAs.

\subsection{The time of fulfilment}

Between 2000 and 2008, the RJAs worked in the Belgian prisons. When they were called upon to speak about the concrete achievements of their work, they usually mentioned 'activities'. These were organised with the prisoners in mind, always took place in precise locations at determined moments, and were carried out by external NGOs (named in italics hereafter). Some of these heterogeneous activities included, for example:

- training inmates in order to raise their awareness of the acts they had committed and of their victims' experience (with Slachtoffer in Beeld in Flanders and Arpège-Prélude in Wallonia);

- training inmates to deal with difficult situations (Omgaan met lastige situaties) as well as organizing Personality Human Resources Training (with $P R H$ in Leuven Central Prison);

- social painting workshops (with Arnica);

- talks between citizens and prisoners over a cup of coffee (Kaffee Detinee in both Leuven prisons);

- discussion groups with citizens (gespreksavonden and gesprekcyclus at the Hoogstraten prison);

- think-tanks (such as the one run by the Janus association at the Marneffe prison);

- mediation programmes aimed at connecting offenders and victims (coordinated by Suggnome in Flanders and Médiante in Wallonia);

\footnotetext{
${ }^{4}$ Indeed, the prisoners in a remand prison are very reluctant to admit an offense for which they have not yet been judged to be guilty.
} 


\section{Dubois Christophe}

- and compensation programmes (with the help of the Compensation Fund) $)^{5}$ (Dubois, 2012a).

Thanks to the work of RJAs, some RJ-oriented activities, and associated words, talks and gestures were introduced into Belgian prisons (Dubois \& Vrancken, 2015). To ensure these activities could take place, the RJAs spent a large part of their time informing the various categories of actors (prisoners, prison guards and governors, psychosocial teams, prison registry etc.) about the idea and activities of RJ. They did so through the distribution of brochures, informal discussions and the organisation of meetings. In addition, the RJAs managed to impart information to prison guards concerning notions of victimisation, civil parties, restoration, victim-offender mediation, responsibilisation etc.

\subsection{Permanent employments but vanishing of the function}

Having been parachuted into a new function, the RJAs integrated into their new environment by organising activities in partnership with external operators, undertaking actions aimed at promoting the concept of RJ and carrying out various missions for the heads of their establishments (Dubois, 2012a). From 2005, the scepticism manifested by prison professionals and the high turnover of the RJAs decreased considerably, which reinforced the idea that they were integrating well. However, it is necessary to nuance the importance of RJ activities in Belgian prisons by emphasizing both their 'reduction' and their 'amplifying' effects (Latour, 1995). Relatively contained, the RJ process attracted the participation of only a few inmates and prison guards, when compared to the overall prison population. Furthermore, it is also necessary to nuance the extent of RJAs' integration in the prison administration, as their employment was still subject to yearly contracts. This situation created a burden of uncertainty in an administration structure where the status of being a fully-fledged public servant was the norm.

From 2005, RJAs undertook preparatory work for their statutarisation and, in May 2007, a recruitment process was organised by the federal administration. Recruitment examinations began in January 2008. In February 2008, the results were published. All the RJAs already in place had to pass

\footnotetext{
${ }^{5}$ An experimental compensation fund for prisoners was established in 2000, managed by Suggnome and sponsored by a charity. Through a process of communication with the injured party, 'an insolvent offender can ask for support by the fund in order to reimburse the victim, on the condition that he carries out volunteer work in the community in consultation with the victim' (Aertsen, 2006: 73).
} 


\section{Dubois Christophe}

the selection exam and some of them were not successful. A period of transition ensued to allow them to serve notice. The era of the permanently employed RJAs began on 2 June 2008. However, on 1 August 2008, the head of the prison administration sent them an email, as well as to the members of the local management teams. In this message, he informed them that 'restorative justice [was] no longer a project stage but a stage in a process'. According to this statement, which was not based on any research or formal evaluation, the mission of the RJAs was officially considered as accomplished. They were invited to take up another function, that of junior director.

The process involved in implementing the ministerial circular of 4 October 2000 reveals an experimental phase of public action, supported essentially by an argument with an axiological content (Dubois and Orianne, 2012). The argument for RJ in the prison environment was made by the central administration for a ten-year period before becoming subject to a neomanagerial argument (Dubois, 2012b) suddenly offering the RJAs new career prospects, notably within direction teams (Dubois, 2016). The structural anchoring of RJ activities that, until then, had depended on their function was affected by this to the extent that the partners in charge of these activities were progressively losing their privileged brokers.

\section{A contrasted policy embeddedness of restorative detention in Flem- ish and French-speaking regions}

The policy of RJ that I have just charted has been implemented in contrasted political and organisational contexts. Let's first remember that Belgium has been a federal state since the reform of 8 August 8 1980. Many responsibilities were at this time transferred from the federal state to the different language communities (Flemish, French and German-speaking) and geographical regions (Flanders, Wallonia and Brussels-Capital). Therefore, the communities became competent in terms of social guidance and assistance, health care, housing, socio-cultural training, professional training, education, sport and leisure.

In Flanders, various associations subsidised by the Flemish community (a unique entity bringing the Flemish community and region together) offer these public services. The Flemish Community Strategic Plan, which was adopted on 8 December 8 2000, aimed at constructing a systematic policy of social assistance (Hellemans et al., 2009). Such an integrated policy was based on collaboration between the federal Ministry of Justice and the Flemish community. In the first instance, the Strategic Plan stated that the Flemish Ministry for Welfare, Health and the Family (Welzijn, volksgezondheid en 


\section{Dubois Christophe}

gezin) was responsible for the social assistance and psychosocial guidance of prisoners. Today, the Strategic Plan employs 17 political coordinators spread throughout each of the Flemish prisons, but also 17 organisational and 10 pedagogical coordinators. These coordinators started, in the early 2000s, to work in direct collaboration with the RJAs, each one offering valuable support to the others (Dubois, 2008b). The idea of RJ is today inscribed in the Strategic Plan and embedded (Laville, 2001) in the Flemish social policy.

On the French-speaking side, the institutional landscape is much more complex and the competences regarding social assistance for the prisoners are distributed between the French-speaking community and the regions of Wallonia and Brussels. And while the various associations active in prison remain reluctant to group together under a single roof $\left(\mathrm{CAAP}^{6}\right)$, the complexity of the field is reflected in the cooperation agreements between the various levels of federal and federated (as the justice system remains a federal competence). The notion of restoration does not appear in these texts. As a consequence, the last RJ-oriented activities organised in French-speaking prisons are the victims-offenders mediations, carried out by Médiante. These are now based on the law of 22 June 222005 'that allows restorative mediation at every stage of the criminal justice process: at the police stage, at the level of the public prosecutor, after prosecution and even during the execution of the sentence' (Lauwaert \& Aertsen, 2016: 346). Of course, the prisoners can no longer count on the RJAs to inform them of this possibility:

'In practice, most of, many of the requests come from the side of the offender. For example, they contact the mediation service after having received information from a judicial body or from the social services in the prison or the probation service, or because they heard about the mediation service from a fellow prisoner' (Lauwaert \& Aertsen, 2016: 347).

However, it is interesting to note that the annual reports of Mediante ${ }^{7}$ and Suggnomé indicate a steady increase in the amount of victim-offender mediation, as illustrated by the table below:

\begin{tabular}{|c|c|c|}
\hline $\begin{array}{l}\text { Civil } \\
\text { Year }\end{array}$ & $\begin{array}{l}\text { Number of victim-offender } \\
\text { mediations carried out by Medi- } \\
\text { ante between } 1 \text { January and } 31 \\
\text { December in French speaking } \\
\text { prisons }\end{array}$ & $\begin{array}{l}\text { Number of victim-offender media- } \\
\text { tions carried out by Suggnomé between } \\
1 \text { January and } 31 \text { December in Flemish- } \\
\text { speaking prisons }\end{array}$ \\
\hline
\end{tabular}

\footnotetext{
${ }^{6}$ This roof is the CAAP platform (http://www.caap.be).
}

${ }^{7}$ Source: http://www.mediante.be/documentation.php 
Dubois Christophe

\begin{tabular}{|c|c|c|}
\hline 2001 & 6 & NA (data not available) \\
\hline 2002 & 22 & NA \\
\hline 2003 & 57 & $\overline{\mathrm{NA}}$ \\
\hline 2004 & 71 & $\overline{\mathrm{NA}}$ \\
\hline 2005 & 89 & 28 \\
\hline 2006 & 111 & NA \\
\hline 2007 & 181 & $\mathrm{NA}$ \\
\hline 2008 & 258 & NA \\
\hline 2009 & 296 & NA \\
\hline 2010 & 305 & 191 \\
\hline 2011 & 339 & 266 \\
\hline 2012 & 298 & 209 \\
\hline 2013 & 335 & 241 \\
\hline 2014 & 343 & 214 \\
\hline 2015 & 373 & 276 \\
\hline 2016 & 326 & 278 \\
\hline
\end{tabular}

The main factor explaining the increasing activity of Médiante and Suggnomé (renamed as Moderator since 2015) lies in the fact that both associations developed the size of their teams until 2008, partly as a consequence of the intermediation of RJAs inside the prisons, but also via the support provided by the law of 22 June 22 2005. The other activities mentioned above (cf. supra section 2.3) could not benefit from similar legal support, and their providers therefore knew different destinies after the vanishing of the RJAs' function: in Flanders, most of them continued working in prison through the Strategic Plan; in Wallonia, most providers disappeared suddenly in 2009.

\section{Current traces and critical questions}

The genesis of the Ministerial Circular of 4 October 2000 reveals the links between academic knowledge and policy (Freeman \& Sturdy, 2015), as criminologists, penologists, and victimologists from K.U. Leuven decisively contributed to the policy inscription of RJ principles and mediation devices 


\section{Dubois Christophe}

in youth (Youth Protection Law of 13 June 2006), criminal (Law of 22 June 2005 ) and prison laws (Prison Law of 12 January 2005).

If these inscriptions show formal traces of RJ, they also give rise to a first critical question concerning the relationship between RJ and the criminal justice system. Defined by many authors as an alternative to retributive and rehabilitative models of justice (Graef, 2000; Braithwaite, 2002; Jaccoud, 2003), can a radical alternative like RJ be institutionalized in the system it aims to challenge? In other words, 'Yet, if restorative justice is supposed to be an alternative to the criminal justice system, why are we doing it in prison?' (Albrecht, 2011: 328). From this perspective, the qualification, in August 2008, by the head of the prison administration of RJ as being 'a process' appeared paradoxical, and even cynical to RJAs and most prison professionals. And the inclusion of RJ in article 9 of the Prison Law might appear as a contradiction (Bastard \& Cardia-Vonèche, 2000): an idea claiming to be an alternative to the prison system while accepting the legal and institutional framework of the same system (Pavlich, 2013).

'The execution of the custodial sentence focuses on the reparation of the harm caused to the victims by the offense, on the rehabilitation of the convicted person and on the individualized preparation of his/her reintegration into the free society' (article 9, Prison Law of 12 January 2005) $)^{8}$.

If the rationality of this article first appeared as an 'achievement' of K.U. Leuven scholars who succeeded in giving sense to the Prison Law, it raises many questions: does it mean that a prison sentence can or must be a time for restoration, reparation, or compensation ${ }^{9}$ ? What is the definition of reparation or restoration? What should be done in cases of irreparable or nonrestorable offenses, and by whom and how should these be defined?

A second critical question is related to the relationship between the recognition of the victim and the retribution of the offender. In order to illustrate this question, I will draw on recent controversies that emerged in February 2018, along with the publication of a book entitled Pourquoi libérer Dutroux ? by Bruno Dayez (2018), the lawyer for Marc Dutroux ${ }^{10}$. It should

${ }^{8}$ « L'exécution de la peine privative de liberté est axée sur la réparation du tort causé aux victimes par l'infraction, sur la réhabilitation du condamné et sur la préparation, de manière individualisée, de sa réinsertion dans la société libre ».

9 It should be noted that the linguistic translation of the verb 'to restore' is, in Dutch, 'herstellen', and in French, can be 'réparer' or 'restaurer'.

${ }^{10}$ Marc Dutroux is a serial child abuser and killer. He was arrested in 1996 and sentenced to life imprisonment in 2004, which amounts in fact to 30 years in prison. 


\section{Dubois Christophe}

be mentioned that, historically, 'the Dutroux Affair' (Kuty, 2008) encouraged some emotionally-driven policy reforms allowing victims to be heard in conditional release procedures. These reforms successively concerned the procedure for conditional release, through a first reform in 1998 (Dubois, 2008a), then through the Law of 2006 implementing the Sentence Enforcement Courts (Bastard \& Dubois, 2016). In brief, the main argument of Bruno Dayez is that the legitimate emotion of victims and public opinion should decrease 20 years after the dramatic events, to the benefit of rationality. And rationality, according to Dutroux's lawyer, consists in acknowledging that a life sentence equals a death sentence for life, and that the law must equally apply to every citizen, since all are human beings, be they Marc Dutroux or anybody else. The reactions of some parents of the children murdered by Dutroux were immediate, as was public opinion. All these reactions were mediated - and amplified - by the press (Denoël, 2018) and social media ${ }^{11}$. The victims and many citizens expressed that they could not understand how such a book could be published. This book and the controversies raised by its publication question the role assigned by - restorative - justice to the victims, and the consequences of this role whenever the victims become - heavily mediatised - opinion leaders, requiring increased retribution for - sometimes irreparable - harm caused by the offender. It also demonstrates the impossible - balance between emotion and rationality, as well as the theoretical conception of the victims as part of the community/society, or as a third dimension beside the offender and the community/society on a schematic triangle such as the one drawn by the French-speaking RJAs (cf. supra, section 2.2). In other words, are the victims 'normal' citizens ? Can and must justice be restorative? Twenty years after the beginning of an experimental policy initiated in Belgian prisons, these questions remain open, and the controversy may be long-lived.

\section{References}

Abdellaoui S., Amadio N., Colin P. (2016). Freins et leviers de la justice restaurative en France. Paris: Mission de recherche Droit et justice.

Aertsen I. (2006). The intermediate position of restorative justice: the case of Bel-

${ }^{11}$ https://www.rtbf.be/info/societe/detail gino-russo-on-nous-a-fait-croire-que-lavictime-aurait-une-place-dans-le-milieu-judiciaire-mais-il-y-a-desretrogrades?id=9844121; http://www.lalibre.be/actu/belgique/un-homme-brulantle-livre-sur-marc-dutroux-arrete-a-bruxelles-5a880f42cd70b558ed672f42. 


\section{Dubois Christophe}

gium. In I. Aertsen, T. Daems \& L. Robert (Eds.), Institutionalizing restorative justice. Cullompton: Willan.

Albrecht, B. (2011). The limits of restorative justice in prison. Peace Review, 23(3): 327-334.

Bastard B., Cardia-Vonèche L. (2000). L'institutionnalisation de l'informel?: la mort d'une bonne idée? L'exemple de la médiation familiale. Informations Sociales, 170(2): 216-230.

Bastard, J., Dubois, C. (2016). Making Sense or/of Decisions? Collective Action in Early Release Process. In Modernisation of the Criminal Justice Chain and the Judicial System. Heidelberg: Springer.

Braithwaite, J. (2002) Setting standards for restorative justice. British Journal of Criminology, 42(3): 563-577.

Britton, D. M. (2003). At work in the iron cage: The prison as gendered organization. New-York: NYU Press.

Crocker, D. (2015). Implementing and Evaluating Restorative Justice Projects in Prison. Criminal Justice Policy Review, 26(1): 45-64.

Dayez, B. (2018), Pourquoi libérer Dutroux? Pour un humanisme pénal, Bruxelles: SAMSA Editions.

Dhami, M. K., Mantle, G., \& Fox, D. (2009). Restorative justice in prisons. Contemporary Justice Review. 12(4): 433-448.

Denoël, T. (2018). Dossier. Faut-il libérer Marc Dutroux ? Le Vif, 47: 42-51.

Dubois, C. (2008a). Restauration et détention en Belgique: genèse de la circulaire ministérielle du 4 octobre 2000. Droit \& Société, 69-70: 479507.

Dubois, C. (2008b). Action publique en détention : décloisonnement, réinsertion et réparation. Le cas d'une prison ouverte'. Recherches Sociologiques et Anthropologiques. XXXIX, 2: 79-103.

Dubois, C. (2012a). La justice réparatrice en milieu carcéral: de l'idée aux pratiques. Louvain-La-Neuve: Presses univ. de Louvain.

Dubois, C. (2012b). Vie et mort d'un métier de l'action publique. Les consultants en justice réparatrice dans les prisons belges. Terrain \& travaux, 20(1): 189-206.

Dubois, C., Orianne J. F. (2012). Les politiques publiques comme partitions à construire. Gouvernement et action publique, 2(2): 117-139.

Dubois, C., Vrancken D. (2015). Restorative detention or 'work on self'? Two accounts of a Belgian prison polic. Ethnography, 16(2): 187-206.

Dubois, C. (2016). Prudence et ruse comme capacités d'action managériale et politique. Le cas des équipes de direction pénitentiaire belges. Sociologie, 7(4): 377-392.

Freeman, R., \& Sturdy, S. (Eds.). (2015). Knowledge in policy: Embodied, inscribed, enacted. Bristol: Policy Press.

Graef, R (2000) Why Restorative Justice? Repairing the Harm Caused by Crime. 


\section{Dubois Christophe}

London: Calouste Gulbenkian Foundation.

Guidoni, O. V. (2003). The ambivalences of restorative justice: Some reflections on an Italian prison project. Contemporary Justice Review, 6(1): 55-68.

Hellemans, A., Aertsen, I., \& Goethals, J. (2009). Gevangenis en samenleving 2009: een externe evaluatie van het Vlaams Strategisch Plan hulp-en dienstverlening aan gedetineerden. Fatik, 121: 17-22.

Immarigeon R. (1996). Prison-based Victim-Offender Reconciliation Programs In B. Gallaway \& J. Hudson (Eds.), Restorative Justice: International Perspectives. New York: Criminal Justice Press.

Jaccoud M (2003) Justice réparatrice et médiation pénale: convergences ou divergences? Montréal: L'Harmattan.

Kuty, O. (1999). Le 'mouvement blanc' en Belgique: un nouvel acteur dans le champ judiciaire? Droit et société, 42(1): 287-310.

Lauwaert K., Aertsen I. (2016). With a little help from a friend: desistance through victim-offender mediation in Belgium. Restorative Justice, 4(3): 345-368.

Laville J.-L. (2001). Les raisons d'être des associations. In J.-L. Laville, A. Caillé et al, et al., Association, démocratie et société civile. Paris: La Découverte.

Pavlich, G. (2013). Governing paradoxes of restorative justice. New-York: Routledge.

Robert, L., \& Peters, T. (2002). Comment la réparation peut dépasser les murs de la prison. Commentaire du projet de « détention réparatrice » en Belgique. In J.-P. Céré (Ed.), Panorama Européen de la Prison. Paris: L'Harmattan.

Vandekerckhove, L., \& Doms, K. (2001). De instroom van generatiestudenten in de criminologische wetenschappen aan de K. U. Leuven, 1985/86 - 1999/00. In T. Peters, L. Dupont \& F. Hutsebaut (Eds.), Herstelrecht tussen toekomst en verleden. Leuven: Universitaire Pers Leuven.

Vanspauwen, K., Robert, L., Aertsen, A., \& Parmentier, S. (2003). Herstelrecht en herstelgerichte strafuitvoering. Een selectieve en geannoteerde bibliografie (Vol. 96). Leuven: Faculteit Rechtsgeleerdheid, Afdeling Starfrecht, Strafvordering en Criminologie. 